\title{
Medical manslaughter in Hong Kong-how, why, and why not
}

\author{
Gilberto KK Leung *
}

\section{A B S T R A C T}

The increasing number of medical manslaughter cases in recent years raises concerns about the concept of criminal liability in medical negligence. Contemporary cases in Hong Kong have also generated debate on whether criminal law intervention is justified and effective at dealing with substandard medical practices. This paper examines the legal principles underlying the applicable legal offence of gross negligence manslaughter and the implications that recent events may have on patient care and the medical profession. The author argues that the criminalisation of medical mistakes can have a detrimental effect on clinical practice and patient

This article was published on $27 \mathrm{Jul}$ 2018 at www.hkmj.org. welfare. At stake is the potential for a loss of mutual trust between the medical profession and the rest of society. Gross negligence manslaughter is an unstable legal concept, and criminal sanctions should at most be applied to conscious violations of established rules and standards but not unintentional errors. As we await the outcomes of ongoing cases in Hong Kong, there is an urgent need to uphold standards of practice and to nurture a robust culture of ethical awareness, compassionate care, and professionalism.

Hong Kong Med J 2018;24:384-90

DOI: $10.12809 / \mathrm{hkmj} 187346$

GKK Leung *, LLM, FHKAM (Surgery)

Department of Surgery, The University of Hong Kong, Pokfulam, Hong Kong

*Corresponding author: gilberto@hku.hk

\section{Introduction}

Medical manslaughter is involuntary manslaughter by gross negligence where patient death has resulted from a grossly negligent (but otherwise lawful) act or omission. ${ }^{1}$ Although related prosecutions remain uncommon, the emergence of recent cases in Hong Kong presents an opportunity to reflect upon whether criminal sanctions are justifiable and effective at dealing with substandard medical practices. This paper begins with an examination of the underlying legal principles, followed by a discussion on how the current direction of travel might impact patient care and the medical profession.

\section{Gross negligence manslaughter}

The applicable legal offence in medical manslaughter is that of gross negligence manslaughter (GNM). ${ }^{1}$ As for civil claims in medical negligence, the legal test to satisfy is that the affected party is owed a duty of care and that a breach of that duty has occurred and caused the injury at issue. ${ }^{2}$ In addition, it must be further established in GNM that the degree of negligence has gone:

"...beyond a mere matter of compensation between subjects and has showed such disregard for the life and safety of others as to amount to a crime against the state and conduct deserving punishment."

The legal test was affirmed in the landmark case of Adomako, in which an anaesthesiologist failed to respond to a disconnection of the oxygen supply during general anaesthesia, whereby the jury had to decide whether "the degree of negligence is so great that a criminal penalty is warranted" ${ }^{4}$ It is ultimately about the transformation of a private wrong into a public one.

\section{Contemporary cases}

Medical manslaughter cases have historically been rare, but a rising trend has been observed in recent years. In the UK, 85 doctors were charged between 1795 and $2005,{ }^{5}$ while 11 cases have already materialised between 2006 and 2013. ${ }^{6}$ A similar situation has occurred in the United States, where over 50 prosecutions have been brought since $1990 .^{7}$ The majority of UK cases involved obstetrics and errors in the prescription or administration of drugs. ${ }^{5}$ Tables 1 and 2 outline the two recent and controversial cases of Mr David Sellu ${ }^{8}$ and Dr Hadiza Bawa-Garba, ${ }^{9}$ respectively.

The first case in Hong Kong involved the misuse of sedative drugs during an illegal abortion for which the doctor was jailed for 2 years in 2003 (Table 3). ${ }^{10}$ A hiatus followed. The highly publicised "DR Group" case saw the conviction of a beauty clinic's owner and technician in 2017; the third defendant, a doctor who gave the treatment, is awaiting a re-trial (Table 4). ${ }^{11}$ In March 2018, a general practitioner was charged after her patient died following a liposuction 4 years prior. $^{12}$ Presently, the family of a 73 -year-old man is 
alleging criminal responsibility on the part of a group of nurses ${ }^{13}$ and a doctor ${ }^{14}$ who were already found guilty of professional misconduct in connection with his death.

Could this be the beginning of a trend in Hong Kong? If so, what could we be wrestling with here?

\section{Medical negligence as crime}

The central and hotly debated question is whether criminal law intervention is justified in cases of fatal medical incidents. ${ }^{15}$ On the one hand, a doctor's license to practice has a legal foundation. Criminal sanctions serve an important punitive function and a symbolic role in restoring public trust when that foundation is not being respected. By holding individuals publicly accountable, criminal sanctions may ensure compliance with professional standards and deter poor and dangerous practices. ${ }^{16}$ In France, for example, a range of criminal offences is available to punish medical mistakes, even when they are

\section{香港醫療誤殺概述}

梁嘉傑

近年醫療誤殺案例有上升趨勢, 引發社會對醫療過失中刑事責任概念 的關注。香港當代案例亦對於刑法干預在處理醫療過失中是否合理和 有效產生爭論。本文探討 「嚴重疏忽誤殺」的法律原則，以及近期案 件對醫療服務和醫療專業界可能產生的影響。筆者認為將醫療過失定 為刑事罪行會對臨床服務和病人福利產生不利影響, 甚至令醫學界和 其他社會人士間喪失互信。「嚴重疏忽誤殺」背後的法律概念缺乏穩 定性, 而刑事制裁最多應適用於有意違反既定規則和標準而非無心之 失。在等待審理中案件的裁決時, 目前迫切需要的是堅持醫療專業標 準, 並培養強而有力的道德意識、仁愛為懷及專業精神的文化。

non-fatal. Jail terms are uncommon; the ultimate force of deterrence lies in the stigma of the charge or conviction itself. ${ }^{17}$

On the other hand, it can be argued that

TABLE I. The case of Mr David Sellu

\section{David Sellu v R (2016) EWCA Crim $1716^{\circ}$}

- In February 2010, a 66-year-old man underwent an elective knee replacement surgery at a private hospital in London. He later developed perforated diverticulitis and was referred to Mr David Sellu, a colorectal surgeon.

- Mr Sellu suspected a bowel perforation but decided to perform a computed tomography (CT) scan first. It was not until 40 hours post-onset that emergency laparotomy was performed. The patient developed multi-organ failure and died.

- Mr Sellu was convicted of gross negligence manslaughter on 5 November 2013 and sentenced to two and a half years' imprisonment. He served 15 months in jail and later appealed.

- His conviction was reversed in November 2016 on the grounds that the trial judge had failed to give the jury sufficient guidance as to the meaning of 'gross negligence'. Furthermore, medical experts had been invited to express opinions on whether Mr Sellu had been grossly negligent, but there was no specific direction by the judge on how these opinions should be regarded by the jury.

- Mr Sellu is currently facing an allegation of professional misconduct by the General Medical Council.

TABLE 2. The case of Dr Hadiza Bawa-Garba

\section{Bawa Garba v R (2016) EWCA Crim 18419}

- A 6-year-old boy was admitted to the hospital on 18 February 2011 for diarrhoea, vomiting, and difficulty breathing. He was seen by Dr Hadiza Bawa-Garba, a specialist registrar, at 10:30 am.

- The doctor ordered a blood test at 10:44 am but did not receive the abnormal results until 4:15 pm due to a computer system failure.

- A chest X-ray, available at 12:30 pm, showed signs of chest infection, but she was not informed of its availability until around 3 pm.

- The doctor was heavily involved in treating other patients.

- She raised the suspicion of pneumonia to a consultant but did not ask the consultant to review the patient.

- She did not specify that enalapril (for the patient's other heart condition) should be discontinued; it was subsequently given.

- The patient later went into arrest. Dr Bawa-Garba responded but mistook the patient for another patient with a do-not-attempt-resuscitation order and called off the resuscitation. The mistake was identified and resuscitation resumed. The patient died at 9:20 pm.

- In November 2015, Dr Bawa-Garba and a nurse were convicted of gross negligence manslaughter; each was given a 2-year suspended jai sentence.

- In June 2017, the Medical Practitioners Tribunal Service (MPTS) suspended the doctor for 12 months and rejected an application from the General Medical Council (GMC) to strike her off the register. The GMC successfully appealed to the High Court to overrule the MPTS's decision. Dr Bawa-Garba was struck off.

- The Secretary of State for Health and Social Care ordered a rapid national review into the application of legal offences to medical cases. The GMC also launched an independent review.

- She was granted an appeal in April 2018 
TABLE 3. The case of Dr Harry Sudirman

HKSAR v Harry Sudirman CACC 486 of $2003^{10}$

- A 31-year-old woman presented with vaginal bleeding in January 2001. She was initially seen by a gynaecologist, who confirmed pregnancy.

- The patient sought a second opinion from Dr Sudirman, who later performed a therapeutic abortion. During the procedure, the patient received an overdose of remifentanil and midazolam for sedation, suffered a cardiac arrest, and died. The cause of death was stated to be 'the adverse effects of remifentanil and midazolam'.

- Dr Sudirman claimed that he had no reason to believe at the time that the patient was pregnant, and that he had performed a dilatation and curettage to enable a diagnosis of a suspected cervical polyp in view of the patient's symptoms.

- It came to light that Dr Sudirman was unfamiliar with the use of remifentanil.

- He was convicted of manslaughter on 30 October 2003 and sentenced to concurrent terms of 12 months and 2 years of imprisonment. His appeal in 2004 was dismissed.

TABLE 4. The "DR Group” case

HKSAR v Chow Heung-Wing, Stephen and 2 others HCCC 437 of $2015^{11}$

- In September 2012, a 31-year-old woman received a transfusion of cytokine-induced killer cells for their alleged anti-ageing benefits at a beauty clinic run by the DR Group in Hong Kong. There was no scientific evidence on the treatment's efficacy.

- The patient later developed signs and symptoms of septicaemia and was admitted to the hospital. Her blood culture grew Mycobacterium abscessus, which was also found on equipment at the clinic's laboratory. The laboratory's technician admitted his failure to screen for bacteria during preparation of the transfusion blood product.

- The owner of the clinic, Dr Heung-wing Chow, and the laboratory technician, Kwun-chung Chan, were convicted of manslaughter in December 2017 and jailed for 12 and 10 years, respectively.

- Dr Wan-ling Mak, the doctor who administered the transfusion, claimed that she was unaware that bacteriological tests had not been carried out on the blood products. She was charged with manslaughter, but the jury was unable to return a majority verdict. A re-trial was granted.

the criminal law is supposed to punish those who cause damages with a morally blameworthy state of mind, whereas misjudgement, inadvertence, or sheer incompetence may be the reasons for a doctor failing to meet standards of care. ${ }^{18}$ Criminal sanctions presume, if not forcibly embed, the role of choice in situations where no choice or decision has been consciously made. This overlooks the notion of blameworthiness as the foundation of the criminal law, and prosecutions were arguably unjustified in at least some cases. ${ }^{19}$ At issue is the appropriateness of the legal test and the threshold for prosecution.

\section{The legal test}

The term "gross negligence" has not been defined, and the legal test established in Adomako has been criticised for its circularity, in that an act or omission constitutes a crime if the jury finds it a crime. ${ }^{7}$ The determination of "grossness" is one for the jury, as directed by the judge; it is a question of law and not for medical experts to address. However, medical experts have occasionally employed their varied understanding of the legal term and provided opinions that could potentially usurp the jury's role. ${ }^{20}$ In the UK, the conviction of Mr David Sellu was reversed because the trial judge had failed to direct the jury properly with regard to the determination of "grossness" and the weight given to the expert opinions on that issue (Table 1$){ }^{8}$ Clearer guidance has since become available; how this will affect judicial practice and outcomes within the UK and other common law jurisdictions, such as Hong Kong, remains to be discovered.

Another contentious aspect of the existing law concerns the mens rea (or "guilty mind") requirement for GNM. A detailed discussion on this highly complex topic is beyond the scope of this paper, and readers are referred to previous works by legal scholars. ${ }^{18,21-23}$ It suffices to say that the culpable mental state in GNM is one of indifference. This can be understood as a state of "wilful blindness" or a high degree of negligence in considering and avoiding obvious risks. ${ }^{18}$ It is (arguably) distinguishable from recklessness, which is acting in the face of subjectively known risks, but less readily so from what is commonly regarded as "inadvertence" or "absent-mindedness" by lay people. ${ }^{23}$

Take for example a hypothetical scenario in which a patient died from septicaemia following a transfusion procedure. While those who consciously disregarded standard safety procedures in preparing the blood product should probably be held criminally liable, it is debatable whether the doctor who gave the transfusion should be so treated. Did the doctor know or suspect the risk of contamination? If not, should he or she have been aware of or considered the possibility of that risk? Was he or she "indifferent"? 
What is the level of due diligence reasonably expected from a doctor administering a treatment passed to him or her by someone else? How much checking is needed, and how should "grossness" be determined in a situation like this? And from an ethical point of view, should the severity of the consequence alone (ie, patient death) transform a common human failing such as "inattention" into a crime? If so, what could this mean in daily clinical practice?

There is no ready answer, and the concept of liability in criminal negligence remains controversial, especially in the medical context. ${ }^{23}$ In the UK, charges against two pharmacists, whose dispensing of a defective medicine caused a child's death, were dropped because of the absence of malicious intent to cause harm, ${ }^{24}$ whereas two junior doctors who inadvertently injected vincristine into a patient's spine were convicted on the grounds that criminal liability may be found not at the time of the injection but when they had "chosen" not to be more careful before acting. ${ }^{25}$ The distinction between these individuals' corresponding mental states is not overly clear, and the legal bar for gross negligence remains disputable. ${ }^{14}$

The situation is further complicated by the fact that a defendant's mental state may be judged either objectively (ie, what a reasonably competent doctor should have been thinking at the time) or subjectively (ie, what the doctor in question was actually thinking at the time) ${ }^{18}$ In the sensationalised case of Dr Conrad Murray, convicted for causing the death of the singer Michael Jackson, it was sufficient for the prosecution to prove that the doctor "should have been aware" of the risks associated with using Propofol outside of a hospital setting, not whether he had actual knowledge of those risks (ie, an objective test). ${ }^{26}$ In contrast, the High Court of Hong Kong had consciously departed from the established English authorities and applied the subjective test in a recent non-medical case. ${ }^{27}$ The debate continues. ${ }^{28}$

\section{Threshold for prosecution}

A charge of GNM even without conviction can be devastating for the doctor involved. In principle, prosecution is brought when it is in the public interest to do so and when there is a realistic prospect of success, but the loosely defined concept of gross negligence affords prosecutors considerable discretion. ${ }^{29}$ Importantly, the criteria for distinguishing between honest mistakes and conscious violations of professional standards are "tests unknown to the criminal law".30 As a result, doctors (or even lawyers) can have little confidence in knowing what kinds of behaviour will attract the attention of the criminal law.

Indeed, prosecutors in the UK have been criticised for prosecuting many doctors who should not have been charged in the first place. ${ }^{19}$ Such prosecutions have caused significant disruptions to the personal and professional lives of innocent individuals and negative feelings within the medical community. ${ }^{31}$ The small number of cases in Hong Kong does not permit a valid assessment, but a reasonable, consistent, and transparent threshold for prosecution would certainly be welcomed. The principle reaffirmed in Mr David Sellu's successful appeal is that a prosecution should not be brought unless the conduct of the doctor involved was "truly exceptionally bad". The mere commission of an error, even if fatal, does not begin to satisfy that test.

\section{Criminal sanctions as a quality assurance measure}

From the public's point of view, an important question is whether criminalisation improves patient safety. There is no empirical evidence to show that it does, and the current understanding of the nature of human error challenges the premise that punishment can prevent mistakes. ${ }^{32}$ Again, a distinction can be made between errors and violations.

Human errors are by nature unintentional. Even the most able and conscientious clinician can commit errors in a complex hospital environment; inexperience, exhaustion, lack of supervision, or systemic failures may be responsible. ${ }^{33}$ Because errors are committed without awareness of the associated risks, they are unlikely to respond positively to the threat of criminal prosecution. ${ }^{34}$ This is particularly the case where health care delivery involves multiple disciplines and professionals whose roles and responsibilities, and hence their duties of care and liabilities, cannot be easily delineated. Moreover, human error is often the last part of a chain of events leading up to an adverse outcome; the proper response should be the adoption of a culture of open disclosure, learning, risk management, and system improvement measures. ${ }^{32} \mathrm{~A}$ case in point is that of Dr Bawa-Garba, in which system factors such as understaffing, lack of supervision, and hardware malfunction are thought to be at least partially responsible for a tragic patient outcome (Table 2).

In contrast, violations are associated with deliberate disregard for patient safety and unjustified risk taking. Adverse outcomes occur primarily because of individual doctors' autonomous decisions rather than the cumulative effects of system and latent factors. The predominance of human agency renders system improvement measures ineffective if not irrelevant; deterrence targeting individuals' attitudes and mental states is needed. ${ }^{22}$ Criminal sanctions in these situations can potentially discourage some doctors' "couldn't care less" attitude and promote a greater sense of responsibility and carefulness. The conduct of Dr Sudirman and the two convicted individuals in the "DR Group" case in Hong Kong fall squarely into this category (Tables 3 and 4). 
Admittedly, the distinction between error and violation is not always straightforward, especially when there are questions about clinical competency. Clinical competency involves a range of human qualities, from skills and knowledge to conscientiousness and ethical standards, only some of which are influenced by threat of criminal penalties. It is notable that criminal sanctions in the early vincristine-related cases did not prevent a recurrence: numerous cases have occurred since. ${ }^{33}$

\section{Diligence or vengeance?}

It has been suggested that the wider use of the criminal law in the present context represents an attempt by the public to exact retribution rather than a desire to improve patient safety. ${ }^{35}$ In the UK, findings from several public inquiries, such as the Bristol Royal Infirmary Report ${ }^{36}$ and the Francis Report, ${ }^{37}$ revealed widespread unethical and substandard practices within the National Health Service. Public dissatisfaction and a deepening blame culture have allegedly created a greater tendency to hold individuals criminally responsible, turning what was once a private matter of civil litigation into a public act of criminal prosecution by the state. ${ }^{38}$

There has at the same time been a gradual but fundamental shift in the way that the medical profession is perceived by society. ${ }^{39}$ Better access to medical information and a stronger emphasis on patients' rights means that doctors are no longer held as high priests of the mysterious art and science of healing but partners in patient journey or providers of services to which taxpayers are entitled. Mistakes are not deemed acceptable simply because medical peers say so; society expects to have the final word. When society thinks that certain behaviours are unacceptable, criminal sanctions can be seen as a ready and legitimate solution. ${ }^{40}$

The medical profession has not taken this well. In the UK, the initial conviction of Mr David Sellu was met with fervent protests. ${ }^{31}$ This surgeon had an otherwise unblemished track record, was held in high regard by his peers and patients, and the penalty imposed on him was seen by some as unjustifiable and disproportionate (Table 1). Similarly, as mentioned previously, the court in Dr Bawa-Garba's case has been strongly criticised for its failure to give due consideration to system factors. ${ }^{41}$ The insistence of the General Medical Council on removing Dr Bawa-Garba from its register caused such an outcry that the UK government decided to launch a national review into the application of the existing law to medical cases (Table 2). ${ }^{42}$ The loss of mutual trust between the medical profession, its regulatory body and the criminal justice system encapsulated in these cases is probably the most damaging effect of the prevailing climate of blame and fear. Patient care may also suffer as doctors become reluctant to disclose their mistakes. Instead of promoting high-quality care, criminalisation could in fact encourage the practice of defensive medicine, stifle compassionate care, alienate the medical profession, and hamper the promotion of a safety culture. ${ }^{43}$

\section{The road ahead}

Reactions from medical peers in Hong Kong towards the two convictions in the "DR Group" case have been restrained. Few appear to condone the negligent practices in that case or disapprove of the penalties imposed (Table 4). There is arguably a sense of detachment, as the circumstances in this case (ie, the preparation of an experimental blood product) are far removed from those commonly experienced by most doctors. As such, we have not seen the kind of emotional responses from within our medical sector that have been found in the UK, where doctors perform routine duties with the knowledge that jail sentences could arise from a single missed diagnosis or a few hours' delay in performing lifesaving surgery.

The outcome of the re-trial of the third defendant in the "DR Group" case could generate more lively discussions for several reasons. First, general opinions vary more widely regarding the wrongfulness of the doctor's conduct. Second, practising clinicians can relate more readily to the circumstances in this part of the case and see the relevance and implications of the re-trial. Third, the legal arguments involved are more complex and subject to debate with respect to the culpability of the doctor's mental state. ${ }^{28}$ Irrespective of the outcome, the ruling will send a strong message on how similar cases will be handled in the future and raise concerns within different sectors of society one way or the other. Ahead of us could be a challenging time.

In the greater scheme of things, there are perhaps good reasons to believe that the general attitude towards the medical profession in Hong Kong has not (yet) become hostile, and that the catalogue of recent cases here is a rare exception. A previous survey showed that the majority of our patients were very satisfied with the quality of care received. ${ }^{44}$ The number of complaints submitted to the Medical Council of Hong Kong has remained steady. ${ }^{45}$ We have not had any public scandal at a comparable scale to those in the UK, and our health care professionals still enjoy a reasonable level of respect. ${ }^{44}$ There is also a handsome degree of transparency and accountability within our system, while institutional measures are in place to ensure that our medical students are properly trained, foreign graduates suitably qualified, and requirements for continuous education diligently followed. ${ }^{46,47}$ All of these factors must be acknowledged, treasured, and enhanced. 
But society's trust in us is not a given; it has to be earned and maintained. Our doctors and nurses work under challenging conditions and need to be supported. ${ }^{48}$ The recent controversy about the suspension of a doctor by the Medical Council mentioned above represents a serious trust crisis that must be addressed urgently. ${ }^{14}$ Meanwhile, we need to train our medical students and trainees well and impart a strong sense of ethical awareness and responsibility so that our patients will remain safe, and know that they are safe, in our hands. ${ }^{49}$ Public education should culture a better understanding of the nature of human error and the acknowledgment of the fact that Medicine is not a perfect science. Lastly, underpinning our right to practice and power to self-regulate is a social contract with society that is built on trust. ${ }^{50}$ The expert opinions we give, how we discuss and handle medical incidents, and the ways in which we respond to legislative efforts to improve patient safety will eventually affect how society perceives and reacts to our mistakes and failings.

\section{Conclusion}

The rising number of medical manslaughter charges and convictions in Hong Kong and overseas poses a concern. Criminal liability for medical negligence is an arguably unstable legal concept, and the prosecutorial threshold and legal test for GNM are imbued with uncertainty. The criminalisation of medical mistakes can potentially create a climate of blame and fear that is damaging to the medical profession and detrimental to patient welfare. From the perspectives of providing deterrence and punishment in the medical context, criminal sanctions should probably be limited to conscious violations of established standards; unintentional errors are better dealt with through professional disciplinary actions or litigation based on the ordinary civil test of negligence. However, this necessitates a fundamental jurisprudential shift that is unlikely to materialise in the near future. As we await the outcomes of ongoing cases in Hong Kong, there is much that we can do to maintain society's trust in the medical profession by upholding standards of care and nurturing a robust culture of professionalism.

\section{Author contributions}

The author has made substantial contributions to the concept or design; acquisition of data; analysis or interpretation of data; drafting of the article; and critical revision for important intellectual content.

\section{Funding/support}

This article received no specific grant from any funding agency in the public, commercial, or not-for-profit sectors.

\section{Declaration}

The author has disclosed no conflicts of interest. The author had full access to the data, contributed to the paper, approved the final version for publication, and takes responsibility for its accuracy and integrity.

\section{References}

1. Crown Prosecution Service, UK Government. Homicide: murder and manslaughter. Available from: http:// www.cps.gov.uk/legal/h_to_k/homicide_murder_and_ manslaughter/\#gross. Accessed 16 Mar 2018.

2. Mason JK, Laurie GT. Mason \& McCall Smith's Law and Medical Ethics. 9th ed. Oxford: Oxford University Press; 2013.

3. R v Bateman [1925] 19 Cr App R 8.

4. Rv Adomako [1995] 1 AC 171.

5. Ferner RE, McDowell SE. Doctors charged with manslaughter in the course of medical practice, 1795-2005: a literature review. J R Soc Med 2006;99:309-14.

6. White P. More doctors charged with manslaughter are being convicted, shows analysis. BMJ 2015;351:h4402.

7. Quick Q. Medicine, mistakes and manslaughter: a criminal combination? Cam Law J 2010;69:186-203.

8. David Sellu v R [2016] EWCA Crim 1716.

9. Bawa Garba v R [2016] EWCA Crim 1841.

10. HKSAR v Harry Sudirman CACC 486/2003.

11. HKSAR v Chow Heung-Wing, Stephen and 2 others HCCC 437/2015.

12. Mok D. Hong Kong doctor arrested on manslaughter charge over death of dancer after beauty treatment. South China Morning Post. 2018 Mar 13. Available from: http://www. scmp.com/news/hong-kong/law-crime/article/2137050/ hong-kong-doctor-arrested-manslaughter-charge-overdeath. Accessed 19 Mar 2018.

13. Tsang E. Hong Kong nurses found guilty of misconduct in fatal blunder or one month. South China Morning Post. 2016 June 13. Available from: http://www.scmp.com/news/ hong-kong/health-environment/article/1974286/hongkong-nurses-found-guilty-misconduct-fatal. Accessed 16 Mar 2018.

14. Cheung E. Hong Kong doctor Wong Cheuk-yi banned for six months over death of elderly cancer patient Wang Keng-kao at Kowloon Hospital. South China Morning Post. 2018 May 9. Available from: http://www.scmp.com/ news/hong-kong/health-environment/article/2145352/ hong-kong-doctor-wong-cheuk-yi-found-guilty. Accessed 10 Mar 2018.

15. Edwards S. Medical manslaughter: a recent history. Ann R Coll Surg Engl 2014;96:118-9.

16. Dekker SA. Criminalization of medical error: who draws the line? ANZ J Surg 2007;77:831-7.

17. Spencer JR, Brajeux MA. Criminal liability for negligence-a lesson from across the Channel? Int Comp Law Quart 2010;59:1-24.

18. McCall Smith A. Criminal negligence and the incompetent doctor. Med Law Rev 1993;1:336-49.

19. Hubbeling D. Criminal prosecution for medical manslaughter. J R Soc Med 2010;103:216-8.

20. Quick O. Expert evidence and medical manslaughter: vagueness in action. J Law Soc 2011;38:496-518.

21. Virgo G. Reconstructing manslaughter on defective foundations. Cam Law J 1995;54:14-6.

22. Horder J. Gross negligence and criminal culpability. U 
Toronto Law J 1997;47:495-521.

23. Smith AM. Criminal or merely human?: the prosecution of negligent doctors. J Cont Health Law Policy 1996;12:13146.

24. March PJ. Boots pharmacist and trainee cleared of baby's manslaughter, but fined for dispensing a defective medicine. Pharmaceutical J 2000;264:390-2.

25. R v Prentice, R v Adomako [1995] 1 AC 171.

26. Kim CJ. The trial of Conrad Murray: prosecuting physicians for criminally negligent over-prescription. Am Crim Law Rev 2014;51:517-40.

27. HKSAR v Lai Shui Yin HCCC 29/2011.

28. Leung JA, Liu HT. Gross negligence manslaughter after Lai Shui Yin. Hong Kong Law J 2014;44:709-17.

29. Quick O. Prosecuting 'gross' medical negligence: manslaughter, discretion, and the crown prosecution service. J Law Soc 2006;33:421-50.

30. O’Doherty S. Doctors and manslaughter-response from the Crown Prosecution Service. J R Soc Med 2006;99:544.

31. McDonald P. Doctors and manslaughter. Bull R Coll Surgeons 2014;96:112-3.

32. Reason J. Human error: models and management. BM 2000;320:768-70

33. Leape LL. Error in medicine. JAMA 1994;272:1851-7.

34. Merry AF. How does the law recognize and deal with medical errors? J R Soc Med 2009;102:265-71.

35. Holbrook J. The criminalisation of fatal medical mistakes BMJ 2003;327:1118-9.

36. Department of Health, UK Government. Learning from Bristol: The Department of Health's response to the report of the Public Inquiry into Children's Heart Surgery at the Bristol Royal Infirmary 1984-1995. 2002. Available from: https://www.gov.uk/government/uploads/system/ uploads/attachment_data/file/273320/5363.pdf. Accessed 18 Feb 2018.

37. UK Government Report of the Mid Staffordshire NHS foundation trust public inquiry. London: The Stationery Office; 2013
38. Radhakrishna S. Culture of blame in the National Health Service; consequences and solutions. $\mathrm{Br} \mathrm{J}$ Anaesth 2015;115:653-5.

39. Edwards N, Komacki MJ, Silversin J. Unhappy doctors: what are the causes and what can be done? BMJ 2002;324:835-8.

40. Leung GK. If we do not take charge of ourselves, some else would (have to). Surg Pract 2016;20:141.

41. Cohen D. Back to blame: the Bawa-Garba case and the patient safety agenda. BMJ 2017;359:j5534.

42. Donnelly L. Hunt orders review of medical malpractice amid doctors' outcry over manslaughter case. The Telegraph. 6 Feb 2018. Available from: https://www. telegraph.co.uk/news/2018/02/06/hunt-ordersreview-medical-malpractice-amid-doctors-outcrymanslaughter/. Accessed 26 Mar 2018.

43. Kessler D, McClellan M. Do doctors practice defensive medicine? Q J Econ 1996;111:353-90.

44. Wong EL, Coulter A, Cheung AW, Yam CH, Yeoh EK, Griffiths SM. Patient experiences with public hospital care: first benchmark survey in Hong Kong. Hong Kong Med J 2012;18:371-80.

45. The Medical Council of Hong Kong. Annual reports 2016. Available from: https://www.mchk.org.hk/files/annual/ files/2016/MCAR_2016_e.pdf. Accessed 26 Mar 2018.

46. The Medical Council of Hong Kong. Hong Kong doctors. October 2017. Available from: https://www.mchk.org.hk/ english/publications/files/HKDoctors.pdf. Accessed 29 Mar 2018.

47. The Hong Kong Academy of Medicine. Positional paper on postgraduate medical education. 2010. Available from: https://www.hkam.org.hk/publications/HKAM_position_ paper.pdf. Accessed 27 Mar 2018.

48. Chow CB. Satisfied patients, burnout doctors! Hong Kong Med J 2012;18:360-1.

49. Wong DS, Lai PB. Malpractice claims: prevention is often a better strategy. Hong Kong Med J 2011;17:425-6.

50. Cruess SR, Cruess RL. Professionalism: a contract between medicine and society. CMAJ 2000;162:668-9. 